\title{
Subnational Variation Across States: A Typology and Research Agenda
}

\author{
Imke Harbers \\ Abbey Steele
}

$\mathrm{C}$ itizens of Ecuador have access to healthcare services in some regions of the country, but its quality varies widely. In neighboring Colombia, children have access to relatively better and more reliable health programs across the country, but in some regions, armed actors extract rents from the healthcare system as they challenge public order (Eaton 2006). Venezuelans have also faced the state's inability to uphold public order, even though for a time in the 2000s, access to education was quite high throughout the country. Eaton notes that compared to Europe, "limited state capacity and highly incomplete processes of state formation have created a fertile landscape for the emergence of much more significant and destabilizing forms of territorial heterogeneity in Latin America" (2017, 6). We define territorial heterogeneity as subnational variation across territorial units in the provision of goods and protection of rights by states. O'Donnell (1999) identified substantial territorial heterogeneity across the region and highlighted how uneven rights protections by the state will necessarily shape the nature of democracy.

The articles in this special issue contribute to a vibrant field that addresses these core issues of state presence and regime type and how they vary subnationally (e.g., Behrend and Whitehead 2016; Ch et al. 2018; Enriquez et al. 2017; Giraudy and Luna 2017; Harbers 2015; Snyder 2001). The articles analyze how the provision of public goods and protection of rights vary across territory within countries. This focus on territorial heterogeneity contrasts with other forms of within-country heterogeneity in access and distribution, such as socioeconomic inequality or variation across ethnic and racial groups (see also Otero-Bahamón 2019; Rogers 2020). In this introduction, we propose a conceptual framework to characterize territorial heterogeneity across states and over time, based on the contributions to the special

Imke Harbers is an associate professor of political science at the University of Amsterdam. I.Harbers@uva.nl. ORCID 0000-0003-1221-4236. Abbey Steele is an associate professor of political science at the University of Amsterdam. A.A.Steele@uva.nl. ORCID 0000-00031126-9235. Conflict of interest: we, Imke Harbers and Abbey Steele, report none.

(C) 2020 The Authors. Published by Cambridge University Press on behalf of the University of Miami. This is an Open Access article, distributed under the terms of the Creative Commons Attribution license (http://creativecommons.org/licenses/by/4.0/), which permits unrestricted reuse, distribution, and reproduction in any medium, provided the original work is properly cited.

DOI 10.1017/lap.2020.4 
issue. In this way, we provide the foundation for a new research agenda to compare forms of subnational variation across states.

Our typology consists of two dimensions: the range of publicly provided goods and guaranteed rights, and their uniformity across the territory. The dimensions of the typology delineate four types of states: broadly uniform, differentiated, narrowly uniform, and disjointed. Broadly uniform and narrowly uniform states both offer some public goods and rights throughout their territories, but the range is more comprehensive in the former than the latter. Narrowly uniform states often prioritize a particular good and try to extend it throughout their territory. Differentiated states offer broad public goods, but only in certain parts of a state's territory, such as the capital and regional cities. Disjointed states do not offer a consistent set of public goods and rights, resulting in a patchwork of sparsely provided goods. The differences among the types of states in our framework are substantively important and reveal different forms of deviation from the Weberian ideal of territorial homogeneity.

We use our typology to illustrate what the special issue articles collectively contribute to our understanding of territorial heterogeneity across states and to identify the new questions they raise. Two recurring themes in this issue are attempts by states to create more uniformity throughout their national territory, and increased uniformity after policy reforms, even when heterogeneity was the goal. The articles show that while many public goods and rights are uneven throughout particular states' territories, some goods and rights have become more uniform over time (e.g., healthcare in Brazil, women's political rights in Mexico), while others remain stubbornly uneven (e.g., property rights in Colombia). Taken together, the articles prompt questions, such as what explains movement toward uniformity across sectors and states? Is unevenness more likely to persist in some sectors than others, and if so, why? Under what conditions do nationwide policy reforms increase territorial heterogeneity?

This introduction offers a brief discussion of the core concepts of the special issue, followed by a short overview of the articles. Against this background, we develop our typology and explain how the articles contribute empirical and theoretical insights in their own right and how they jointly push forward our understanding of subnational variation across states. Subsequently, we place this in the context of the literature on states and state building in Latin America, and we identify promising areas for future research.

\section{How SHOuld We Conceptualize TERRITORIAL HETEROGENEITY?}

This special issue is concerned with how the state varies subnationally. Prominent conceptualizations of the state imply that strong states provide public goods, especially order and protection, throughout their territory (e.g., Weber 1947; Tilly 1985). This understanding informs Mann's influential definition of infrastructural power as "the capacity of the state actually to penetrate civil society, and to implement logistically political decisions throughout the realm" $(1988,5)$. In contrast, we take state presence as variable throughout the realm, and focus on the heterogeneous 
provision of goods and protection of rights. We argue that there are different forms of such territorial heterogeneity, and that grouping them together under the banner of overall weakness undermines our ability to understand them. This is particularly true in Latin America and across the developing world, where few states meet the ideal of broad and territorially uniform public goods provision. Even strong statesthose with "sufficient resources for the maintenance of an effective bureaucratic and administrative state" (Steinberg 2017, 225)—do not deploy these resources evenly across their territory. Furthermore, even if resources are invested equitably, outcomes across territory may differ. This heterogeneity is substantively important.

Because scholars of the state have tended to think of strength and homogeneity as closely related, heterogeneity-much like state weakness-has often had an implicitly negative connotation in the literature on state building. In civil war studies, the state's limited presence in peripheral areas has been associated with the onset of civil war-even though, by most definitions, a civil war would indicate a weak state (Kocher 2010). Indeed, we may observe civil war because relatively stronger states choose to fight challengers rather than ignore them. More recent work on subnational conflict points out that a host of possible arrangements between state and nonstate actors-both armed and unarmed — are compatible with modern states (Staniland 2017; Post et al. 2017).

The literature on decentralization and comparative territorial politics has also recognized the potential benefits of heterogeneity in governance. Federalism makes it possible to accommodate distinct linguistic or cultural communities within a country (Hooghe and Marks 2016). This offers a strategy for "holding together" countries that might otherwise dissolve into territorial conflict (Stepan 1999). Arranging governance so that subnational units play an important role formally recognizes that preferences for public goods provision may vary and that in certain situations, territorial heterogeneity may be preferable to the coercive enforcement of uniformity (see also Staniland 2012).

Territorial heterogeneity also has implications for rights protections. O'Donnell's key concern (1999) was whether heterogeneous states would be able to enforce the equal citizenship required for democracy. An important body of scholarship on the territorial dimension of democratization has since demonstrated that Latin American states vary not only in how effective state institutions are throughout the territory, but also in how consistently citizens' political, civil, and social rights are enforced across subnational units (e.g., Cornelius 1999; Gervasoni 2010; Gibson 2013; Giraudy 2015).

The articles in this special issue focus both on rights protections and public goods provision across subnational jurisdictions (Giraudy et al. 2019). Rights and goods vary within states' territories at different scales, such as municipalities (Sánchez-Talanquer, Otero-Bahamón, and Cleary this issue), provinces (Paredes and Došek), and states (Giraudy and Pribble). Throughout this introduction, we refer to them collectively as regions, because the term broadly captures a subnational point of potential variation. Which territorial scale or level of analysis is appropriate probably depends on the outcome of interest and on the proposed theoretical mechanism (Soifer 2019). 


\section{Subnational Variation Across States IN LATIN AMERICA: AN OVERVIEW OF THE SPECIAL ISSUE}

The articles in this special issue cover five countries in Latin America: Argentina, Brazil, Colombia, Mexico, and Peru. The analyses focus on a range of policy sectors and document within-country variation in core state activities, such as the provision of public health services and the protection of property rights. They also demonstrate territorial heterogeneity in the guarantee of individual and collective rights, focusing specifically on women and indigenous citizens.

The article by Jenny Pribble and Agustina Giraudy focuses on health outcomes in Argentina, Brazil, and Mexico and asks under which conditions countries move toward uniformity in outcomes. While territorial inequality in health outcomes declined substantially in Brazil, Mexico saw only a moderate decline and little change, followed by a limited decline in Argentina in the aftermath of decentralization. Two factors account for this divergence in trajectories, Giraudy and Pribble argue. First, if the decentralization push comes from national technocrats rather than from bottom-up pressure by nonstate actors, health outcomes are less likely to become more equitable over time. Second, the strength of coordination and oversight mechanisms by the central government also plays an important role in reducing territorial variation in outcomes.

Silvia Otero-Bahamón also examines how and why key healthcare outcomesspecifically, infant and maternal mortality—vary across Colombian municipalities. Her analysis shows that the national policy framework in the sector and whether the policy is "place-sensitive" shape the well-being of local populations. A one-size-fitsall or "place-blind" approach to policy is likely to compound subnational differences. Her analysis highlights that reducing territorial heterogeneity requires the state to design and implement tailored policies to achieve similar outcomes in different local circumstances.

Mariano Sánchez-Talanquer also highlights territorial unevenness in Colombia, but his analysis focuses on fiscal capacity and the quality of cadasters. Where conventional theories of state building would expect the quality of both of these aspects of state activity to covary because the legibility of assets facilitates taxation (Scott 2009), his article shows that the opposite pattern emerges. He demonstrates that while property holders sought to have their property claims recognized and registered in cadastral records, they evaded taxation by manipulating the assessment process to systematically undervalue the land. In doing so, they created the unevenness in property rights and extraction that continues to characterize the Colombian state.

Whereas Sánchez-Talanquer highlights how unevenness can be an unintended consequence of state-building projects, the article by Matthew Cleary shows how efforts to preserve local autonomy can actually result in increasing uniformity. The formal recognition of autonomy in communities that already enjoyed substantial de facto control over local governance created a legal mechanism through which the constitutionality of local practices could be challenged. Cleary examines how this 
played out with regard to women's political rights, as the principle of gender equality established in the national legal framework created a contested issue in communities that had long restricted women's participation in public life.

The territorial unevenness of political inclusion and indigenous representation is also demonstrated in the article by Maritza Paredes and Tomáš Došek on Peru. While the context was not favorable for ethnic parties at the national level, outcomes at the subnational level varied. These authors' analysis-based on extensive fieldwork-identifies cohesive indigenous organizations and political capital as necessary and jointly sufficient for the substantive representation of indigenous interests in the political arena. Crucially, though, their findings highlight that descriptive and substantive representation do not go hand-in-hand in the subnational cases they study. The extent to which indigenous citizens are included in the political system-either descriptively or substantively—thus varies territorially.

The contribution by Kent Eaton takes variation across subnational units as a given and outlines the methodological challenges inherent in studying territorial heterogeneity. Instead of conceptualizing subnational units as independent, he argues, scholars need to consider carefully whether and how variables located outside the unit influence local outcomes. He distinguishes between vertical influences, which come from the national level or the international level, and horizontal influences, which arise through the interaction between subnational units at the same level. The articles by Otero-Bahamón and Cleary in this issue constitute examples of theorizing vertical relationships. Otero-Bahamón studies the role of the national policy framework in explaining subnational variation in basic health outcomes, and Cleary points to the role of new laws provoking local changes in political representation.

Each of these articles contributes new data on subnational variation and new theories on its causes and consequences. Here, we draw on these insights to characterize states based on their territorial heterogeneity. This exercise allows us to generate new questions about state building based on the special issue articles and to highlight how the articles contribute to establishing a new research agenda.

\section{A TyPology OF Territorial Heterogeneity}

The articles in the special issue all illuminate aspects of O'Donnell's 1999 conceptual map, on which distinct zones indicate varying performance of state institutions and the rule of law. He notes that democratic states in Latin America claim to establish and guarantee social order throughout their national territory. Empirically, though, the extent to which states actually provide order and guarantee rights varies widely across the territory. How can we characterize and study this heterogeneity? How can we draw on the wealth of evidence about subnational variation to "scale up" to the national level (Giraudy and Pribble 2019)?

We present a new typology of states to address these questions. We conceive of states as differentiated sets of institutions that uphold citizens' rights and provide public goods to the population of a specific territory, over which they have de jure 
Figure 1. Conceptual Typology of States

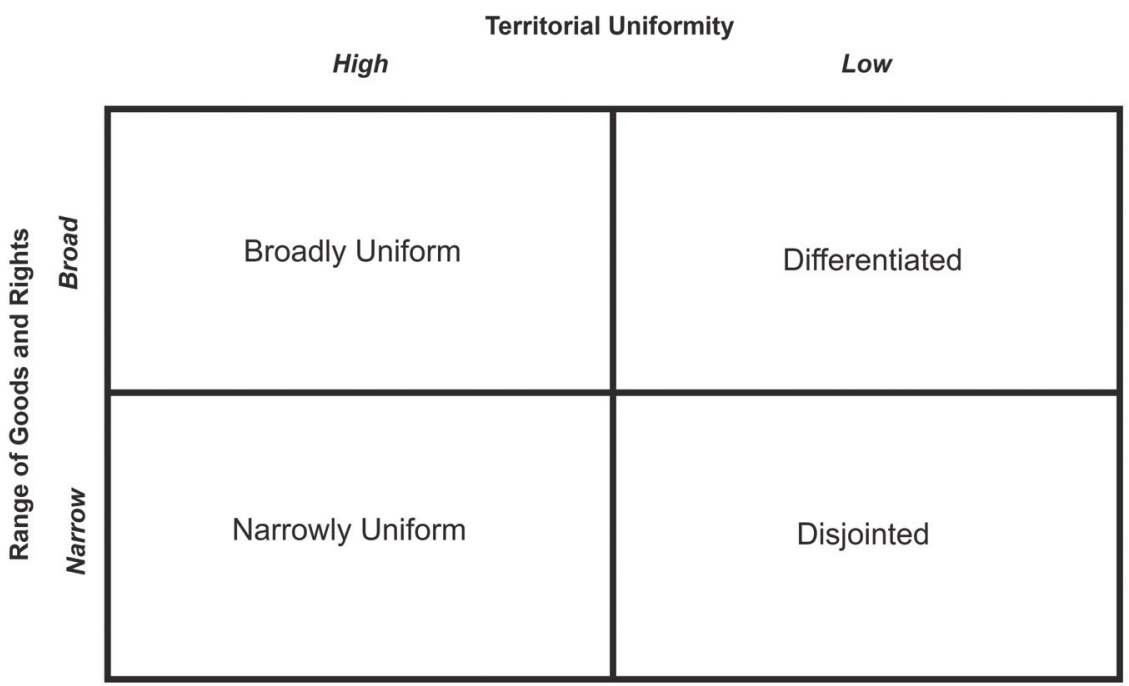

authority (see also Mann 1988). We focus on contemporary states, which differ from their historical antecedents in the range of public goods they provide to citizens and in the range of citizen rights they formally recognize (Skocpol and Amenta 1986; Poggi 1990; Desai 2003). ${ }^{1}$

Our typology identifies variation in two dimensions: the range of goods and rights provided by the state and the territorial uniformity of their provision. These goods, as illustrated by the articles in this special issue, include health, security, education, and infrastructure, as well as the rule of law and a clean environment. ${ }^{2}$ The rights we refer to guarantee equality before the law, as well as participation in the political system and equal participation in society more broadly. Based on our two dimensions, figure 1 distinguishes four types of states.

The first dimension refers to the range of public goods provided and rights protected by the state. By range, we mean "how many" or "comprehensiveness," and the typology is agnostic as to which specific goods or rights a state provides in a particular place. Previous scholarship has sometimes viewed this range as a logical hierarchy, in which states initially focus on minimal functions (law and order, property rights, public health), then expand to intermediate functions (basic education, environmental protection), and finally graduate to activist functions like fostering markets (see, e.g., World Bank 1997). Our typology presupposes no such hierarchy. Across Latin America and the developing world, states have invested in the provision of goods, such as pensions or health insurance, despite severe shortcomings with regard to functions like public health and order (Banerjee et al. 2008, 3119; Fukuyama 2004, 2013). Moreover, as the article by Sánchez-Talanquer in this issue highlights, even fundamental aspects of state building like property rights and taxa- 
tion do not necessarily go together. Empirically, certain combinations probably occur more regularly than others, but we leave this as an open question.

The second dimension captures the degree of territorial uniformity in goods provided and rights protected. Though some places in a state may have comprehensive public goods and rights, this breadth of provision is often uneven throughout the territory. Goods and rights may be delivered in a variety of forms. As the contributions to the special issue highlight, the provision of goods and services often involves governments at different levels (e.g., Giraudy and Pribble; Otero-Bahamón). For our classification, it does not matter whether they are provided by the central government, by regional or local governments, or through the cooperation of different levels of government. What matters, instead, is whether any part of the state provides these goods, either directly or by closely regulating and monitoring private providers so that they are available in a given region (see Harbers 2015; Post et al. 2017). This multilevel view of the state is informed by the literature on decentralization and multilevel governance (Hooghe et al. 2016; Niedzwiecki et al. 2018).

Jointly, these two dimensions can be illustrated by a $2 \times 2$ table that allows us to classify territorial heterogeneity in public goods provision and rights protections. Of the four quadrants, only the first is homogenous. The other three are characterized by significant heterogeneity, albeit of different types. States can shift from one type to another over time. Differentiated or disjointed states can become narrowly uniform states following a concentrated policy push (e.g., Otero-Bahamón; Giraudy and Pribble) or due to the unintended consequences of a reform (e.g., Cleary). Moreover, states can become disjointed if public goods provision breaks down. The current crisis in Venezuela forcefully illustrates this point. The typology allows us to put the articles in this issue in dialogue with one another, and to raise new research questions.

\section{The Broadly Uniform State}

The broadly uniform state has long served as the implicit model of an ideal-typical "strong state" for the state-building and state capacity literature (Mann 1988). Nevertheless, its incidence is geographically and temporally limited. This type of state provides a comprehensive range of public goods to citizens throughout the territory. The quintessential examples are Nordic welfare states that provide a broad range of public goods and uniformly guarantee the rights of their citizens. The central government plays an active role in coordinating and financing public goods, even though subnational governments are often in charge of implementation and monitoring (Sellers and Lidström 2007; Rokkan 1970). Across Latin America, empirical examples of similar states are scarce. O'Donnell $(1999,138)$, focusing especially on the territorial dimension of the rule of law, identifies Costa Rica, Chile, and Uruguay as examples of "relatively high homogeneity." 


\section{The Differentiated State}

The differentiated state also provides a broad range of public goods, but has large territorial differences in the location and types of goods provided and rights protected. As a result, the way the state shapes citizens' lives in different regions of the country differs substantially. Differentiated states may vary from a wide range of public goods in some areas and very few in other regions to relatively plentiful goods in many areas with diverse constellations of those goods across the country.

Three countries that demonstrate the range of differentiated states in the Americas are Colombia, Brazil, and Peru. In Colombia, before its 1991 Constitution and subsequent decentralization efforts, some regions of the country offered a wide range of public goods, particularly in regional cities, while others remained virtually untouched by the government (Soifer 2016). The articles on Colombia by OteroBahamón and Sánchez-Talanquer illustrate subnational inequality in public goods provision in crucial policy sectors. Similarly, contemporary Peru provides fairly comprehensive public goods in the capital, while it formally delegates responsibility for public goods provision in large concessions to nonprofit organizations and corporations in the Amazon (Eaton 2015).

Contrary to the broadly uniform state, where one national vision is enforced across distinct subnational units, public goods "baskets" in the differentiated state could potentially be tailored toward local needs or preferences, as suggested in the fiscal federalism literature (Oates 2005; Rogers 2020). Yet as the contribution by Paredes and Došek on Peru demonstrates, the extent to which different groups can influence the policy process and exercise their political rights varies across subnational units. Moreover, the political process in subnational units is not necessarily democratic. The article by Sánchez-Talanquer on property rights and taxation in Colombia demonstrates that the preferences of subnational elites often play an outsized role in determining the local basket of goods that the state provides. They push for the goods and services they find most appealing and-if the provision of resources from the central government is limited-for which they are willing to shoulder the tax burden (see also Faust and Harbers 2012; Soifer 2016). As a result, subnational public goods baskets may not necessarily be aligned with the preferences of local citizens, and how much different groups influence what goods the state prioritizes is a separate, important question.

\section{The Narrowly Uniform State}

The narrowly uniform state prioritizes a limited range of public goods and provides them uniformly throughout the territory. The provision of these goods extends even to marginalized areas. Across Latin American states, there is significant cross-country variation in how consistently the state pushes the expansion of certain goods throughout its territory and whether it is successful in doing so. In this issue, Giraudy and Pribble and Otero-Bahamón focus on the role of healthcare expansion across Mexico, Brazil, Argentina, and Colombia. The authors find that over time, inequalities in health outcomes within the countries declined. However, each coun- 
try followed different paths to increasing uniformity of outcomes. The articles highlight the importance of coordination and cooperation across levels of government for successful public goods delivery.

The specific sector that states prioritize for uniformity probably varies over time. Mid-twentieth-century corporatism could be conceptualized as a state project of narrow uniformity. During the heyday of the "corporatist citizenship regime," states sought to expand their societal and territorial reach by investing in organizations that provided land to rural populations and access to agricultural subsidies. Yashar's 1999 analysis highlights the shift from one imperfect attempt at narrow uniformity to another. As the result of neoliberal influences, states rolled back the distribution of benefits through corporatist organizations and pushed a uniform legal order with individual property rights instead. The article by Matthew Cleary in this issue shows how this new project challenged indigenous autonomy in Mexico.

Beyond the priority public goods, local public goods provision varies in narrowly uniform states. In some regions, it may be on a par with regions in the differentiated state, whereas in others there is little state provision beyond the priority goods. Overall, the narrowly uniform state is characterized by significant heterogeneity with regard to nonpriority goods.

\section{The Disjointed State}

In the disjointed state, public goods are not provided in a systematic or territorially uniform manner. Resources devoted to public goods provision vary territorially, as there is no nationwide strategy to compensate for regional disparities. The state may provide some goods in some regions, but compared to the other three types, public goods provision is more limited in terms of range and territorial reach. The result is a patchwork of sparsely provided goods. In such states, nonstate actors, like insurgent groups, churches, and NGOs, may provide goods locally. Though they may coordinate with state institutions, they are just as likely to operate independently (Post et al. 2017). Some regions may not experience any regular provision of public goods.

The clearest example of a disjointed state in Latin America is Venezuela in recent years. The humanitarian crisis has exposed the state's withdrawal from the provision of basic supplies to its population, including medicine and healthcare, beyond Caracas. Armed groups are stepping in to fill gaps in some regions, even in the absence of a civil war (Kurmanaev 2020). Venezuela's experience, moving from one of the more robust differentiated states in the region (O'Donnell 1999; Soifer 2016) to perhaps the most disjointed, is a stark illustration of how states can shift over time. Other instances of states that do not consistently provide basic goods and rights throughout the territory are Honduras and El Salvador.

To illustrate the types of states delineated by our typology, figure 2 displays the distribution of five public goods and rights (A, B, C, D, E) across four regions that make up a hypothetical state. In the broadly uniform state, the full range of goods is available in all regions. In the differentiated state, only the top-left region has the full basket, and despite the overall broad range of goods, the number of goods per 
Figure 2. Public Goods Across Regions by Type of State

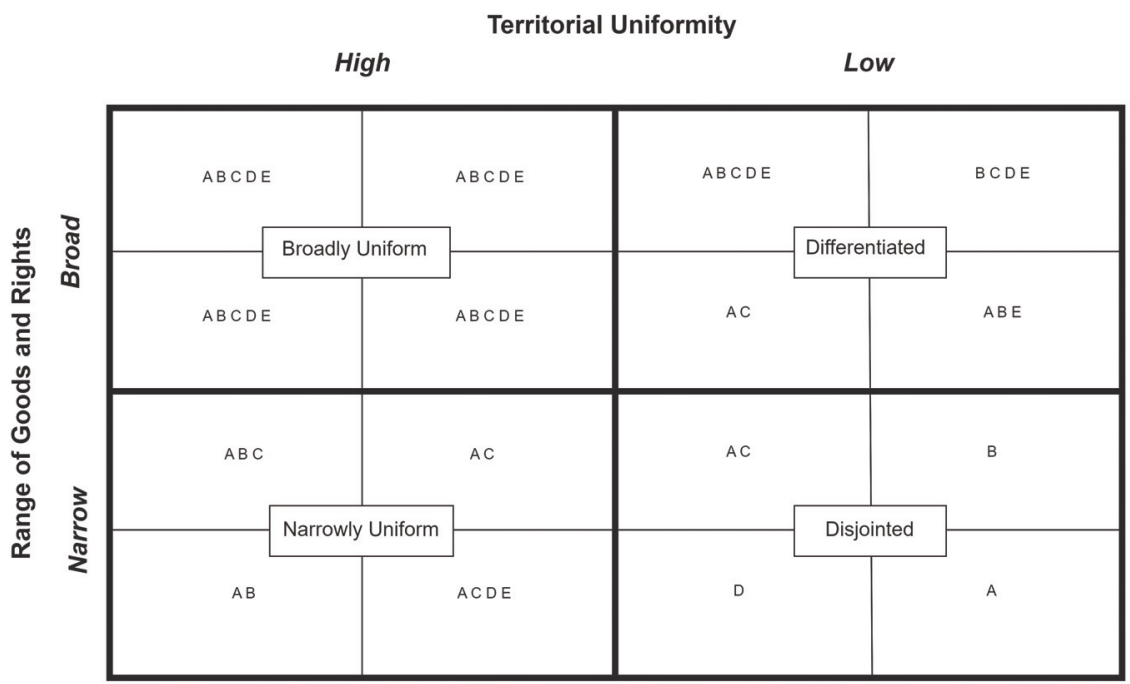

region varies. In the narrowly uniform state, by contrast, good $A$ is available in all regions, even as the range of state-provided goods varies. In the disjointed state, the range of goods is limited, and no good is available consistently.

Note that the differentiated, narrowly uniform, and disjointed state each contain a region in which the state provides goods $A$ and $C$, but that each of these regions is embedded in a different national context. The two dimensions of the typology thereby allow us to identify relevant variation across countries. Our typology provides flexibility to scale back up to the national level by asking how the state fulfills its core activities throughout the territory (see also Giraudy and Pribble 2019 on scaling up). ${ }^{3}$ The typology avoids a normative commitment to what the state should do or look like. Focusing on what the state does within its borders allows us to conceptualize variation across states in a new way. Furthermore, the variation it highlights, illustrated empirically by the contributions to the special issue, often defies expectations derived from the literature on state building in Europe, such as the notion of an orderly sequence of public goods expansion and that of states steadily moving toward territorial homogeneity (Weber 1947; Marshall 1965; Tilly 1985). 


\section{RESEARCH Agenda: \\ WHAT EXPLAINS HETEROGENEITY OR UNIFORMITY?}

The articles in this issue point to and suggest answers for new and important questions. Under which conditions do policies intending to produce uniformity succeed, and when do they fall short? When do policies to preserve subnational autonomy and heterogeneity backfire and lead to greater uniformity instead? And when do state-building efforts that aim to create uniformity result in heterogeneity? Who are the key actors driving uniformity or resisting it? What are the structural factors that contribute to the state types? How do goods and rights covary within states? Is there a sequence of public goods provision that is more likely to lend itself to broader uniformity? What is the relationship between types of territorial heterogeneity and democratic governance?

The articles in this issue highlight the need to distinguish between uniformity as an intended policy goal and as the actual outcome of reforms. Giraudy and Pribble, for instance, study cases in which decentralization reforms were associated with more uniform outcomes in the health sector. They find that the bottom-up nature of the reform coalition in Brazil, which included a social movement actively promoting the expansion of health care, was associated with more uniformity than the top-down nature of reforms in Argentina and Mexico.

In Colombia, it was not until place-sensitive approaches were adopted that outcomes became more uniform across regions (Otero-Bahamón). Policies that are place-blind and do not consider variations in local circumstances are likely to compound preexisting inequalities between units. In Mexico, Cleary reveals a contrasting relationship between the intention of reforms and the actual outcome. $\mathrm{He}$ demonstrates the increased uniformity of women's political rights in spite of policies explicitly intended to preserve difference across subnational units. In contrast, measures to protect indigenous political representation in Peru did not lead to uniformity, as Paredes and Došek show. What explains which types of policies retain subnational variation, or in which contexts variation is preserved? The articles in this issue answer these questions by revealing the role of new actors, in addition to structural and geographic conditions.

So far, the literature on state building has emphasized the role of elites, especially at the subnational level, in promoting or impeding state formation (Boone 2012). In explaining the lack of territorial homogeneity across Latin American states, this literature shows how subnational powerholders resisted efforts to strengthen central authority after independence (Centeno 2002; Centeno and Ferraro 2013; Kurtz 2013; Soifer 2015). The interests and preferences of subnational elites then played an outsized role in shaping public goods provision, often resulting in a patchwork of goods that persists to the present (e.g., Dell 2010; Garfias 2018). Adding to the work on historical legacies of state formation, the new contemporary actors identified here include social movements (Giraudy and Pribble), technocrats (Otero-Bahamón; Giraudy and Pribble), courts (Cleary), political parties (Paredes 
and Došek), and international actors, such as NGOs or development organizations (Eaton), unwittingly or not.

For the case of Mexico and the unintended expansion of women's political rights, Cleary identifies the courts as decisive actors, prioritizing uniform constitutional rights for individuals over protections for indigenous autonomy. For Paredes and Došek, no such court oversight guarantees the forms of representation for any given community in Peru. Instead, political parties determine the extent of substantive indigenous representation across communities. In Mexico, Argentina, and Brazil, Giraudy and Pribble point to the importance of distinct reform coalitions for achieving uniform outcomes across regions. Eaton, in turn, demonstrates the need to think through how international actors may influence national and subnational outcomes. Collectively, the articles find that a broad variety of actors influence the extent of uniformity that states achieve in a given policy area or sector. An important line of inquiry for future research on the role of actors in contemporary processes of state building is to explore which actors are relevant and influential across sectors and under what conditions they are able to achieve their goals.

Identifying the relevant actors for particular outcomes is also a key way to avoid the sort of methodological pitfalls that Eaton identifies. Are threats to subnational unit independence likely to come from horizontal relationships among the units, such as those that may be fostered when a social movement is active in multiple regions of a country? Or does the embeddedness of subnational units in vertical relationships, and their interaction with institutions, such as courts or parties, influence outcomes within units? Answering these questions should guide scholars in their approach to subnational analysis. Importantly, as this collection of articles illustrates, the answers to these questions are likely to vary across the set of public goods or rights that the state is theoretically responsible for providing or protecting.

In addition to highlighting the role of actors, the articles in this special issue speak to the continued importance of geographic and demographic factors that have historically worked against state penetration in Latin America (e.g., Centeno and Ferraro 2013). In this literature, rugged terrain, low population density, and distance from the capital have been identified as structural conditions that rendered the provision of public goods in peripheries prohibitively expensive for states with limited resources (Herbst 2000; Pierskalla et al. 2017). Against this historical backdrop, one question that emerges is whether technological advances in communication and transportation could provide ways for a contemporary state to become more uniform. Otero-Bahamón's article in this issue highlights the continuing importance of structural variables, such as population density and geography, despite advances in technology. She argues that ignoring such structural differences is likely to compound subnational variation. Relevant questions for future research are which conditions lead states to design and implement place-sensitive policies, and when do those policies specifically address territorial heterogeneity. The articles in this issue, especially the contributions by Otero-Bahamón and Giraudy and Pribble, show that contemporary states sometimes develop policies to promote uniformity even in seemingly adverse circumstances. 
Beyond the determinants of uniformity in specific policy sectors, the contributions also raise questions about the relationship between types of subnational variation across different types of public goods or sets of rights. While Colombia made strides to increase equitable health outcomes across regions, the state's attempts to provide more uniform property rights and to improve the quality of cadasters were consistently undermined (Sánchez-Talanquer this issue). The state's ability to tax effectively therefore remains stubbornly uneven across municipalities, even as it has been able to achieve more uniformity in the field of public health. The contrast between Otero-Bahamón's and Sánchez-Talanquer's findings shows that states can achieve greater uniformity in some sectors, even while failing to do so in others. What explains this divergence across sectors?

The literature on state building suggests two sets of explanations for variation across sectors that merit further research. First, achieving uniformity may be more challenging in some sectors than in others, primarily on the basis of how complex the provision of a certain good is (e.g., Dargent 2015). When the provision of a good is fairly straightforward, uniform provision may be possible even when local circumstances vary. The article by Sánchez-Talanquer suggests, however, that the difficulty of registering property versus assessing its value does not satisfactorily explain why differences across these two areas of state activity persist. This puzzle points to the need to explicitly consider variation in state strategies (Geddes 1996) and in which goods and rights are prioritized in a given time period.

The literature on state building also shows that state builders see certain types of goods as more important than others. For instance, state expansion in Europe in the late nineteenth century tended to emphasize educational reforms (Anderson 1991; Weber 1976). Vaughan's 1997 work on postrevolutionary Mexico also illustrates the importance central elites assigned to public education as a key ingredient in forging a modern nation. Between 1923 and 1936, the number of teachers in rural areas grew from 690 to 16,079 (Vaughan 1997, 12), and the provision of education explicitly included marginalized areas (see also Soifer 2013 on education in Peru). A key question for further research is how a particular type of public good is selected for uniform provision.

Another question that emerges from this divergence across sectors is whether the prioritization of certain goods and rights influences the success of state-building projects. Are they more likely to persist if certain types of goods (e.g., public education in a national language, a nationwide infrastructure network) are prioritized early on (Darden and Mylonas 2015; Soifer 2016)?

Furthermore, the articles in this special issue also raise doubts about the assumption of a hierarchy of goods provision. Latin American countries have the highest rates of lethal violence in the world. Nevertheless, the articles in this issue show that Mexico and Colombia-with extreme levels of lethal violence and the longest-running insurgency, respectively—have made significant strides in improving uniformity in health outcomes across their territories. This is consistent with findings in the civil war literature, which has shown that armed groups often operate alongside state institutions at the local level (Mampilly 2011; Arjona 2014; Harbers 
et al. 2016; Ch et al. 2018). Some states are able to provide a broad set of public goods across their territory, even as they are unable to achieve uniformity in protecting their citizens from violence.

Crucial questions moving forward are why and under what conditions states invest in expanding the provision of goods and rights, even when order has not been established. A related line of inquiry is when and where the lack of public order undermines the provision of other public goods. More generally, how sectors covary within a state can also differ quite a bit across states, and implies that looking at only one sector may yield an incomplete view of territorial heterogeneity in a given state. Common conceptualizations of the state imply that strong states provide core public goods, especially order and protection, throughout their territory, and that any deviation from territorial homogeneity is a form of weakness. Our conceptual typology explicitly calls attention to how uniformly the state provides a range of goods, highlighting the need to take a broader view of state activity across the territory.

A particularly urgent question is the compatibility of different types of territorial heterogeneity with democracy. While O'Donnell's 1999 work would lead us to expect more successful democracies in broadly uniform than in disjointed states, it is less clear how differentiated or narrowly uniform states might perform. What is the relationship between democracy at the national level and types of territorial heterogeneity? Which types of states succeed in engaging citizens and in producing programmatic and representative parties? Bridging questions about the regime and the state, we can also ask how successfully different types of states reflect the underlying preferences of the population, instead of viewing these differences through the lens of incomplete or ineffective state formation.

The conceptual typology we present here is agnostic about the origins of territorial heterogeneity, but this question deserves further consideration. Increasing uniformity by extending public goods and sets of rights to peripheral communities is not necessarily a benign process and may be highly contentious (Staniland 2012). The expansion of women's rights enforcement to indigenous communities in Mexico illustrates this point (Cleary this issue). When studying (successful) attempts to increase uniformity, it is therefore worth considering the extent to which this is a preferred outcome by local communities. To improve the quality of citizens' lives, what is effective, and desirable, given the type of state that exists? In this way, our typology and the articles in this special issue provide some guidance for contemplating important normative trade-offs between national-level goals of inclusion and representation and subnational autonomy.

\section{NoTES}

For helpful feedback, the authors thank Carla Alberti, Matthew Cleary, Kent Eaton, Agustín Goenaga, Johannes Lindvall, Juan Pablo Luna, Alison Post, Melissa Rogers, Rich Snyder, Hillel Soifer, the anonymous reviewers of the journal, and participants in workshops at the University of Amsterdam in March 2017, the Pontificia Universidad Católica de Chile in December 2017, and the University of Gothenburg in June 2019. We also thank Eleanor Lahn, who skillfully and generously shepherded the special issue through the editorial 
process. Imke Harbers gratefully acknowledges the financial support of a Marie Curie Fellowship from the European Commission (\#656361).

1. Though such public goods could also be provided by nonstate actors (Post et al. 2017), we focus here only on those provided by the state.

2. We follow the political science literature that discusses such goods and services under the label of public goods (see Saylor 2012; Golden and Min 2013), even though they often do not live up to the classic definition of public goods as being nonexcludable and nonrivalrous (Cornes and Sandler 1996). Even though these goods are not uniformly available to all citizens in the territory, they are "beneficial for a large group" (Desai 2003, 68) in the relevant region, and they generate positive externalities for people who do not pay for their provision.

3. Our focus in the special issue and this introduction is on states, and therefore we emphasize the utility of our framework for scaling up to the national level. The typology may also be relevant for other units characterized by internal heterogeneity. In cities, for instance, public goods provision often varies considerably across neighborhoods.

\section{REFERENCES}

Anderson, Benedict. 1991. Imagined Communities: Reflections on the Origin and Spread of Nationalism. London: Verso.

Arjona, Ana. 2014. Wartime Institutions: A Research Agenda. Journal of Conflict Resolution 58, 8: 1360-89.

Banerjee, Abhijit, Lakshmi Iyer, and Rohini Somanathan. 2008. Public Action for Public Goods. Handbook of Development Economics, vol. 4. Amsterdam: North Holland. 311754.

Behrend, Jacqueline, and Laurence Whitehead. 2016. Illiberal Practices: Territorial Variance Within Large Federal Democracies. Baltimore: Johns Hopkins University Press.

Boone, Catherine. 2012. Territorial Politics and the Reach of the State: Unevenness by Design. Revista de Ciencia Politica 32, 3: 623-41.

Centeno, Miguel A. 2002. Blood and Debt: War and the Nation-State in Latin America. University Park: Pennsylvania State University Press.

Centeno, Miguel A., and Agustín E. Ferraro, eds. 2013. State and Nation Making in Latin America and Spain: Republics of the Possible. Cambridge: Cambridge University Press.

Ch, Rafael, Jacob N. Shapiro, Abbey Steele, and Juan F. Vargas. 2018. Endogenous Taxation in Ongoing Internal Conflict: The Case of Colombia. American Political Science Review 112, 4: 996-1015.

Cornelius, Wayne A. 1999. Subnational Politics and Democratization: Tensions Between Center and Periphery in the Mexican Political System. In Subnational Politics and Democratization in Mexico, ed. Cornelius, Todd A. Eisenstadt, and Jane Hindley. La Jolla: Center for U.S.-Mexican Studies, University of California, San Diego. 3-16.

Cornes, Richard, and Todd Sandler. 1996. The Theory of Externalities, Public Goods, and Club Goods. Cambridge: Cambridge University Press.

Darden, Keith. and Harris Mylonas. 2015. Threats to Territorial Integrity, National Mass Schooling, and Linguistic Commonality. Comparative Political Studies 49, 11: 1446-79.

Dargent, Eduardo. 2015. Technocracy and Democracy in Latin America: The Experts Running Government. New York: Cambridge University Press.

Dell, Melissa. 2010. The Persistent Effects of Peru’s Mining Mita. Econometrica 78, 6: 1863 1903. 
Desai, Meghnad. 2003. Public Goods: A Historical Perspective. In Providing Global Public Goods: Managing Globalization, ed. Inge Kaul, Pedro Conceição, Katell Le Goulven, and Ronald U. Mendoza. Oxford: Oxford University Press. 63-77.

Eaton, Kent. 2006. The Downside of Decentralization: Armed Clientelism in Colombia. Security Studies 15, 4: 533-62.

- 2015. Disciplining Regions: Subnational Contention in Neoliberal Peru. Territory, Politics, Governance 3, 2: 124-46.

- 2017. Territory and Ideology in Latin America: Policy Conflicts Between National and Subnational Governments. Oxford: Oxford University Press.

Enriquez, Elaine, Martin Sybblis, and Miguel Angel Centeno. 2017. A Cross-National Comparison of Sub-National Variation. American Behavioral Scientist 61, 8: 90831.

Faust, Jörg, and Imke Harbers. 2012. On the Local Politics of Administrative Decentralization: Applying for Policy Responsibilities in Ecuador. Publius: The Journal of Federalism 42, 1: 52-77.

Fukuyama, Francis. 2004. The Imperative of State-Building. Journal of Democracy 15, 2: 1731.

- 2013. What Is Governance? Governance 26, 3: 347-68.

Garfias, Francisco. 2018. Elite Competition and State Capacity Development: Theory and Evidence from Post-Revolutionary Mexico. American Political Science Review 112, 2: 339-57.

Geddes, Barbara. 1996. Politician's Dilemma: Building State Capacity in Latin America. Bedrkeley: University of California Press.

Gervasoni, Carlos. 2010. A Rentier Theory of Subnational Regimes: Fiscal Federalism, Democracy, and Authoritarianism in the Argentine Provinces. World Politics 62, 2: 302-40.

Gibson, Edward L. 2013. Boundary Control: Subnational Authoritarianism in Federal Democracies. Cambridge: Cambridge University Press.

Giraudy, Agustina. 2015. Democrats and Autocrats: Pathways of Subnational Undemocratic Regime Continuity Within Democratic Countries. Oxford: Oxford University Press.

Giraudy, Agustina, and Jennifer Pribble. 2019. Rethinking Measures of Democracy and Welfare State Universalism: Lessons From Subnational Research. Regional and Federal Studies 29, 2: 135-63.

Giraudy, Agustina, Eduardo Moncada, and Richard Snyder. 2019. Subnational Research in Comparative Politics: Substantive, Theoretical, and Methodological Contributions. In Inside Countries: Subnational Research in Comparative Politics, ed. Giraudy, Moncada, and Snyder. Cambridge: Cambridge University Press. 3-54.

Golden, Miriam, and Brian Min. 2013. Distributive Politics Around the World. Annual Review of Political Science 16: 73-99.

Harbers, Imke. 2015. Taxation and the Unequal Reach of the State: Mapping State Capacity in Ecuador. Governance 28, 3: 373-91.

Harbers, Imke, Rivke Jaffe, and Victor J. N. Cummings. 2016. A Battle for Hearts and Minds? Citizens' Perceptions of Formal and Irregular Governance Actors in Urban Jamaica. Politica y Gobierno 23, 1: 97-123.

Herbst, Jeffrey. 2000. States and Power in Africa: Comparative Lessons in Authority and Control. Princeton: Princeton University Press.

Hooghe, Liesbet, and Gary Marks. 2016. Community, Scale, and Regional Governance: A Postfunctionalist Theory of Governance. Vol. 2. Oxford: Oxford University Press. 
Hooghe, Liesbet, Gary Marks, Arjan H. Schakel, Sara Niedzwiecki, Sandra Chapman Osterkatz, and Sarah Shair-Rosenfield. 2016. Measuring Regional Authority: A Postfunctionalist Theory of Governance. Vol. 1. Oxford: Oxford University Press.

Kocher, Matthew Adam. 2010. State Capacity as a Conceptual Variable. Yale Journal of International Affairs 5, 2: 137-45.

Kurtz, Marcus J. 2013. Latin American State-Building in Comparative Perspective: Social Foundations of Institutional Order. Cambridge: Cambridge University Press.

Kurmanaev, Anatoly. 2020. Rural Venezuela Crumbles as President Shores Up the Capital and His Power. New York Times, January 13. https://www.nytimes.com/2020/01/13/ world/americas/Venezuela-collapse-Maduro.html

Mampilly, Zachariah. 2011. Rebel Rulers: Insurgent Governance and Civilian Life During War. Ithaca: Cornell University Press.

Mann, Michael. 1988. The Autonomous Power of the State: Its Origins, Mechanisms and Results. In States, War and Capitalism: Studies in Political Sociology, ed. Mann. Oxford: Blackwell. 1-32.

Marshall, Thomas H. 1965. Class, Citizenship, and Social Development: Essays. Garden City: Anchor Books.

Niedzwiecki, Sara, Sandra Chapman Osterkatz, Liesbet Hooghe, and Gary Marks. 2018. The RAI Travels to Latin America: Measuring Regional Authority Under Regime Change. Regional and Federal Studies. DOI 10.1080/13597566.2018.1489248.

Oates, Wallace. 2005. Toward a Second-Generation Theory of Fiscal Federalism. International Tax and Public Finance 12: 349-74.

O’Donnell, Guillermo. 1999. Counterpoints: Selected Essays on Authoritarianism and Democratization. Notre Dame: University of Notre Dame Press.

Otero-Bahamón, Silvia. 2016. When the State Minds the Gap: The Politics of Subnational Inequality in Latin America. Ph.D. diss., Northwestern University.

. 2019. Subnational Inequality in Latin America: Empirical and Theoretical Implications of Moving Beyond Interpersonal Inequality. Studies in Comparative International Development 54, 2: 185-209.

Pierskalla, Jan, Ana Schultz, and Erik Wibbels. 2017. Order, Distance, and Local Development over the Long-Run. Quarterly Journal of Political Science 12, 4: 375-404.

Poggi, Giancarlo. 1990. The State: Its Nature, Development, and Prospects. Stanford: Stanford University Press.

Post, Alison E., Vivian Bronsoler, and Lana Salman. 2017. Hybrid Regimes for Local Public Goods Provision: A Framework for Analysis. Perspectives on Politics 15, 4: 952-66.

Rogers, Melissa. 2020. Federalism and the Welfare State in Latin America. Regional and Federal Studies, April. DOI https://doi.org/10.1080/13597566.2020.1749841

Rokkan, Stein. 1970. Citizens, Elections, Parties. Oslo: Universitetsforlaget.

Saylor, Ryan. 2012. Sources of State Capacity in Latin America: Commodity Booms and State Building Motives in Chile. Theory and Society 41, 3: 301-24.

Scott, James C. 2009. The Art of Not Being Governed: An Anarchist History of Upland Southeast Asia. New Haven: Yale University Press.

Sellers, Jefferey M., and Anders Lidström. 2007. Decentralization, Local Government, and the Welfare State. Governance 20, 4: 609-32.

Skocpol, Theda, and Edwin Amenta. 1986. States and Social Policies. Annual Review of Sociology 12: 131-57.

Snyder, Richard. 2001. Scaling Down: The Subnational Comparative Method. Studies in Comparative International Development 36, 1: 93-110. 
Soifer, Hillel. 2013. Elite Preferences, Administrative Institutions, and Educational Development During Peru's Aristocratic Republic (1895-1919). In Centeno and Ferraro 2013. 247-68.

- 2015. State-Building in Latin America. Cambridge: Cambridge University Press.

. 2016. Regionalism, Ethnic Diversity, and Variation in Public Good Provision by National States. Comparative Political Studies 49, 10: 1341-71.

- 2019. Units of Analysis in Subnational Research. In Giraudy et al. 2019. 92-112.

Staniland, Paul. 2012. States, Insurgents, and Wartime Political Orders. Perspectives on Politics 10, 2: 243-64.

2017. Armed Politics and the Study of Intrastate Conflict. Journal of Peace Research 54, 4: 459-67.

Steinberg, Jessica. 2017. "Strong" States and Strategic Governance: A Model of Territorial Variation in State Presence. Journal of Theoretical Politics 30, 2: 224-45.

Stepan, Alfred. 1999. Federalism and Democracy: Beyond the U.S. Model. Journal of Democracy $4,1,19-34$.

Tilly, Charles. 1985. War Making and State Making as Organized Crime. In Bringing the State Back In, ed. Peter B. Evans, Dietrich Rueschemeyer, and Theda Skocpol. Cambridge: Cambridge University Press. 169-91.

Vaughan, Mary Kay. 1997. Cultural Politics in Revolution: Teachers, Peasants, and Schools in Mexico, 1930-1940. Tucson: University of Arizona Press.

Weber, Eugen. 1976. Peasants into Frenchmen: the Modernization of Rural France, 1870 1914. Stanford: Stanford University Press.

Weber, Max. 1947. The Theory of Social and Economic Organization. Ed. Talcott Parsons. Trans. A. M. Henderson and Talcott Parsons. London: William Hodge and Company.

World Bank. 1997. World Development Report: The State in a Changing World. New York: Oxford University Press.

Yashar, Deborah J. 1999. Democracy, Indigenous Movements, and Postliberal Challenge in Latin America. World Politics 52, 1: 76-104. 